\title{
Dynamics of Production Activities of Women Farmers in Songan Village, Bangli Regency
}

\author{
Luh Indrayani ${ }^{1, *}$ Lucy Sri Musmini ${ }^{1}$ Ni Wayan Ayu Santi ${ }^{1}$
}

\author{
${ }^{1}$ Department of Economics and Accounting, Universitas Pendidikan Ganesha, Singaraja, Indonesia \\ *Corresponding author. Email: luhindrayani25@gmail.com
}

\begin{abstract}
This study has the aims to determine the dynamics of the production activities of women farmers in Songan Village, Bangli Regency. Production activities in agriculture aim to increase work productivity. This type of research is qualitative using grounded research method to explore social processes that occur in women farmers. As many as 6 informants explained things related to production activities that has been carried out every day. The results showed that the production activities of women farmers in Songan Village were related to the quality and quantity of production, profit, meeting needs, maintaining survival, and the purpose of earning wages.
\end{abstract}

Keywords: Production, Productivity, Women farmers.

\section{INTRODUCTION}

The women's courage in developing their abilities other than only as housewives needs to be appreciated, because this is supported by the will, ability and hard work as a must-have capital. Women always take part in everything that happens in family life, especially in the economy. This is in accordance with [1] which stated that women play an important role in the economic development of families and communities. Based on this belief, women will be able to achieve the success that is their goal with various work efforts carried out and their ambitions. The involvement of women in agriculture does not only help men in working on agricultural land, but also plays a role from the beginning to the end of the process. In fact, the work carried out by women is heavier than that of men, because women also have to carry out the role of being a housewife and as a mother to their children. The role of women farmers is carried out for the family so that they are still able to maintain food security so that they are able to support the family's needs. Farming activities on agricultural land take a long time from morning to evening. In agriculture, the role of women is very substantial during the production process, starting from selecting superior seeds, preparing the land, planting, maintaining, harvesting, and marketing products. The involvement of women in the production process takes place on an ongoing basis. Such a routine will certainly bring consequences with reduced time to do other activities. Women farmers prepare themselves starting from the morning, cooking for family needs and bringing supplies to the farm. Afternoon activities return to duties as a housewife before taking a break to restore energy. This situation occurs in every area in Bali that has agricultural land worked by women farmers.

Bangli Regency is one of the regencies in Bali that has excellent potential in agriculture and horticulture. This is supported by the land being fertile and very suitable for cultivation by planting various types of plants. Based on statistical data obtained information that $41.63 \%$ of Songan villagers work as farmers. The administrative division of the territory divides Songan Village into Songan A Village and Songan B Village. Working as a farmer is dominated by women, this can be seen from statistical data (2019) that $19.16 \%$ are male; $19.76 \%$ women in Songan A Village and $21.19 \%$ men; $23.09 \%$ of women in Songan B work as farmers. Based on these data, it is clear that more women are farmers, this of course provides the same opportunities and even more roles than men in agriculture. Songan Village as one of the villages as a producer of vegetable commodities in Bangli Regency. This can be seen from the statistical sources of Bangli Regency in 2019, the production of vegetable commodities in Bangli Regency consists of vegetables in the form of onions, cabbage, chilies, tomatoes and beans with a total of 64,757 tons of agricultural products. The data proves that women farmers have a big role in economic activities to produce commodities from agricultural land. 
Various economic activities in the agricultural sector aim to help meet the needs of the family, so that women are not dependent on the income of their husbands as the head of the family. This statement is reinforced by [2] that gender equality means the equality and equality of the roles of women and men both in the domestic sphere and in the public sector. This equality will provide a special spirit for women in exploring their potential to work harder in managing the various resources they have. Women can empower their resources for various economic activities. Economic empowerment of women can increase gender equality [3]. This statement is in line with [4] that gender equality is a key factor in economic development. In an effort to realize this, it is necessary to motivate women to be economically independent [5] so that women play an important role in reducing poverty through productive work [6].

In agricultural activities in Songan Village, each individual has duties and responsibilities that are carried out for certain purposes through commitments formed from each individual. There are important things such as cooperation, trust, kinship, solidarity, justice and honesty of every farmer. This situation is in line with the statement [7] which reveals that social norms such as reciprocity, trust, and justice are the basis for developing public policies to increase social benefits and cooperative behavior. Every economic activity will require various parties to achieve the planned goals. The economic activities in question start from production, distribution and consumption [8]. Of course, in its implementation there are various dynamics in women farmers. Activities carried out by women farmers are in the form of production processes that require economic resources and parties who take the initiative to manage these resources so as to produce the products needed.

Production activities are carried out as an effort to produce a product, both goods and services. With the existence of production activities, it is expected that the goods or services produced can meet consumer needs and benefit from the goods/services produced. Various efforts are needed in the process of converting inputs into outputs to meet human needs. With limited resources and the variety of human needs, it is necessary to carry out production activities as part of economic activities to produce goods that are human needs. Individuals can no longer produce the goods and services they need themselves, so they need other parties to do so through a certain process that is carried out on an ongoing basis. All forms of production activities require factors of production such as factors of production of natural resources, human resources, factors of production of capital and entrepreneurship. The objectives of production activities [9] include (1) meeting various human needs; (2) seeking profit; (3) maintain business continuity; (4) increase the quality and quantity of production.
Factors of production are needed in economic activity to produce goods and services. Types of production factors [10] consist of: (1) natural resources, various things that are available in nature and can be used to fulfill needs; (2) human resources, labor used in the production process to create new products or increase the added value of a product; (3) capital, everything that supports the production process; and (4) entrepreneurship, in the form of activities carried out starting from planning, organizing, directing, and evaluating. Various factors of production are needed and have different needs in each different activity. In agricultural production, farmers can combine these production factors in order to achieve the highest efficiency both physically and economically.

This is interesting to study considering the complexity of production activities in generating income for each female farming family. In this condition, the writer wants to examine the study of the dynamics of the production activities of women farmers in Songan Village, Bangli Regency. This research will contribute to the science of production activities in the economic field.

\section{METHOD}

This study uses a grounded research method [11] used to explore social processes that occur in human interaction. Collecting data in this study through interviews and observations, with data analysis from Strauss \& Corbin in the form of coding [12] [13]. There were 6 women farmers in Songan Village who became informants. This number represents the region and the interviewed informants have provided maximum information, so that with this number no additional new information is obtained. They explain things related to production activities that are carried out every day. The results of the interview are then given analysis and meaning so that it is clearly illustrated the dynamics of production activities that occur in female farmers in Songan Village, Bangli Regency.

\section{RESULTS \& DISCUSSION}

This research was conducted on female farmers in Songan Village, Bangli Regency who carry out production activities as farmers. The production activities are intended to meet the needs and welfare of life. Activities carried out to produce goods or services with the results of production activities seen from transactions that make money.

Production activities in agriculture for women farmers in Songan Village are strongly supported by geographical factors. The area of Songan Village has relatively high rainfall and has rugosely soil types and former Mount Batur lava flows that support various plants to thrive. With natural supporting factors, it is 
very potential for agriculture to produce superior horticultural commodities. The female farmers of Songan Village have been educated by their parents from a young age to become farmers. They are taught from generation to generation how to manage land because it has become a habit to rely on their lives on agricultural land. This also helps them in planting suitable types of plants to be planted on the land of Songan Village. Armed with the knowledge and ability of female farmers, they carry out farming activities that plant more types of onions. They carry out these activities with various aims for the welfare of life. The following are the results of interviews about the production activities carried out by the informants.

The first informant (KS), a female farmer who already has a child who is studying at a university. She always tries to meet the needs of children to get an education with the hope that their children will have higher abilities in terms of education. the following is his narrative (Table 1).

Table 1. Narrative of KS

\begin{tabular}{|c|c|c|}
\hline$R:$ & $\begin{array}{l}\text { "Based on your daily } \\
\text { activities, why do you want } \\
\text { to do activities as a } \\
\text { farmer?" }\end{array}$ & $\begin{array}{l}{ }^{1} \text { Children's } \\
\text { Need } \\
{ }^{2} \text { Wage }\end{array}$ \\
\hline I: & $\begin{array}{l}\text { "I work as a farmer } \\
\text { because I am sending my } \\
\text { children to Undiksha. } \\
\text { From the results I get a } \\
\text { wage of Rp. 100,000.00 a } \\
\text { day. I will continue to do } \\
\text { this work as a steady } \\
\text { source of income. With } \\
\text { tenacity to take care of } \\
\text { plants so they don't fail to } \\
\text { harvest." }\end{array}$ & $\begin{array}{l}{ }^{3} \text { Production } \\
\text { Quantity }\end{array}$ \\
\hline
\end{tabular}

Table 2. Narrative of NS

\begin{tabular}{ll}
\hline$R:$ & "What do you do as a farmer ${ }^{1}$ Daily Need \\
& for what?" \\
I: $\quad$ "I am a farmer because my & \\
& parents are also farmers. I ${ }^{2}$ Wage \\
& work with people, because I \\
& don't own it, but I am a \\
& smallholder farmer and earn \\
& IDR 100,000 a day. I use this \\
& to help make ends meet."
\end{tabular}

According to KS, the activities carried out as female farmers are able to help meet the cost of their children's education in college. Through the perseverance that you have as a farmer, you always try to cultivate agricultural land so that the results from farming onions do not fail to harvest. Thus, the wages earned can be used to meet the needs of his life.

The second NS informant is a 44-year-old woman, who does onion farming to fulfill her daily needs. The following (Table 2) is a statement from an NS informant.

NS assumes that working as an onion farmer is able to help her husband's income in meeting household needs. With the wages earned NS tries to use money wisely. This means that the abilities possessed by the inheritance of parents are able to help meet the needs of life. Thus, NS always tries to work diligently to obtain maximum yields.

The next informant was LB who also followed in the footsteps of his parents as a farmer. The feeling of being happy to be a farmer and waiting for the harvest is a matter of pride, especially when the onion harvest is satisfactory. Here's his narrative (Table 3).

Table 3. Narrative of LB

\begin{tabular}{|c|c|c|}
\hline$R:$ & $\begin{array}{l}\text { "Why do you choose to do } \\
\text { activities as a farmer, is } \\
\text { there a certain motive?" }\end{array}$ & $\begin{array}{l}{ }^{1} \text { Maintaining } \\
\text { Survival }\end{array}$ \\
\hline I: & $\begin{array}{l}\text { "I am happy as a farmer, } \\
\text { because it has been passed } \\
\text { down from generation to } \\
\text { generation, my parents are } \\
\text { also farmers. I followed in } \\
\text { the footsteps of my parents. } \\
\text { Although there is no } \\
\text { assistance from the } \\
\text { government, it is not a } \\
\text { problem for me. I am happy } \\
\text { to wait for the harvest time } \\
\text { which only ranges from once } \\
\text { every } 2-3 \text { months with a } \\
\text { yield of up to } 8 \text { quintals of } \\
\text { onions. If there is no certain } \\
\text { planting technique, it is still } \\
\text { the same as the way we used } \\
\text { to work together. I will } \\
\text { continue to do farming } \\
\text { activities, hopefully the next } \\
\text { generation will be more } \\
\text { successful than us now }\end{array}$ & $\begin{array}{l}{ }^{2} \text { Quality and } \\
\text { Production } \\
\text { Quantity }\end{array}$ \\
\hline
\end{tabular}

LB's enthusiasm as a farmer raises his own motivation to gain profit/profit from onion production. With a technique that has been carried out for generations, it is able to maintain the quality and quantity of onion production that is managed together. This is of course to maintain survival as a farmer. These agricultural products are used to meet the needs of life 
and help workers who participate in working on their land.

Another story was told by KY, who works as a female farmer because her husband is a farmer. KY works to meet the needs of the kitchen and other household needs. This activity can be done every day. Here's his narrative (Table 4).

Table 4. Narrative of KY

\begin{tabular}{|c|c|c|}
\hline$R:$ & $\begin{array}{l}\text { "Is there a special reason for } \\
\text { you to do activities as a } \\
\text { farmer??" }\end{array}$ & $\begin{array}{l}{ }^{1} \text { Fulfilling the } \\
\text { daily need }\end{array}$ \\
\hline$I:$ & $\begin{array}{l}\text { "I am doing farmer work } \\
\text { because I help my husband } \\
\text { who works as a farmer. I work } \\
\text { to meet the needs of the kitchen } \\
\text { and other household needs. I'm } \\
\text { here as a worker only, and } \\
\text { earn Rp. 100,000.00 every day. } \\
\text { My way of farming is like other } \\
\text { people grow onions. There } \\
\text { haven't been any other events } \\
\text { I've tried to do. Usually once } \\
\text { harvested the amount is up to } \\
800 \text { kg". }\end{array}$ & $\begin{array}{l}{ }^{3} \text { Production } \\
\text { Quantity }\end{array}$ \\
\hline
\end{tabular}

Helping her husband who works as a farmer is the main reason for a KY, even though it is only as a worker whose aim is to get a wage, it makes KY diligent in his profession. However, these female farmers are able to meet their daily needs in the kitchen and other needs from their work as farmers.

It is the same with PS, who is a female farmer who will continue to plant onions in order to earn money. This goal can also help husbands in meeting household needs. Here's his narrative (Table 5).

Table 5. Narrative of PS

\begin{tabular}{|lll|}
\hline$R:$ & $\begin{array}{l}\text { "Why do you do the job of being } \\
\text { a farmer because usually this job } \\
\text { is for men?" }\end{array}$ & Need \\
& & \\
& & \\
& "I want to earn money from & \\
& working as an onion farmer. & \\
& Helping husbands in meeting & \\
& household needs. This 2-3- & \\
& month harvest really helps my & \\
& household finances"
\end{tabular}

The money from PS's work is used for household needs. This is also very helpful to ease the burden on the husband who is still lacking in finances. Every day there are expenses to sustain life, so PS hopes that the results of his hard work will be useful in sustaining a better life.
Unlike the case with JS who is a hobby as a farmer. Even though he already has a main job as a TU worker at school, it doesn't stop his hobby. While on vacation, JS works as a farmer with the aim of increasing the kitchen money. Here's his narrative (Table 6).

Table 6. Narrative of JS

\begin{tabular}{|c|c|c|}
\hline$R:$ & $\begin{array}{l}\text { "Why do you work as a farmer } \\
\text { when you already have a main } \\
\text { job?" }\end{array}$ & $\begin{array}{ll}1 & \text { Daily } \\
\text { Need } & \end{array}$ \\
\hline$I:$ & $\begin{array}{l}\text { "It is purely my hobby to do this } \\
\text { job. I have worked as } \\
\text { administrator, but my heart has } \\
\text { always wanted to work as an } \\
\text { onion farmer" }\end{array}$ & $\begin{array}{l}2 \\
\text { Maintaining } \\
\text { Survival }\end{array}$ \\
\hline
\end{tabular}

JS uses every opportunity he has to pursue his hobby as a farmer. The income earned is used to meet the needs of the kitchen and maintain a good life in the work they do in a balanced way.

The production activities carried out by women farmers in Songan Village have various goals to be achieved. Some things do have something in common, but other things they do with different expectations. Whatever and however the way that women farmers take, the ultimate goal is to meet their needs and achieve a prosperous life.

The production activities of women farmers in Songan Village in the agricultural sector are based on several things that are the goals for each activity carried out. Through interviews conducted, women farmers assumed that they carried out onion production activities on agricultural land to earn wages, meet kitchen/daily needs and other household needs, increase the quality and quantity of production, and maintain survival.

Every wage received will be used to meet daily household needs, increase husband's income, paying for children's education costs, buying routine needs every month and carrying out religious activities, both traditional and social in the community. The money earned can benefit each female farmer with different management. They realize that the manifestation of gratitude to God is important for health and safety at work and in daily life. The management of hard-earned money at work is used sparingly, wisely, prioritizing primary needs and sticking to the priority scale.

Efforts to increase the quality and quantity of production are also the hope of every farmer. They try to work hard using the best possible way for maximum results. Each period of tillage must be successful away from crop failure. This is a spirit that has been embedded in the hearts of every female farmer. With the hereditary abilities possessed by women farmers, they also have an impact in cultivating the land, because 
experience remains the best teacher in the business they run. From this activity, the hope of the ancestors is maintained in the survival of agriculture in the village. Each harvest will be a long-awaited moment for proud results that benefit all women farmers. Based on this explanation, it is in line with the opinion [9] that production activities aim to meet human needs, seek profit, maintain business continuity and increase the quality and quantity of production. Women farmers continue to strive to maintain their profession by increasing the amount of production so that the quality is also increasing. This will attract consumers to remain customers, consumers who already have satisfaction with children's products become loyal to use the goods produced.

\section{CONCLUSION}

Based on the data presented, it can be concluded that the production activities of women farmers in Songan Village are related to the quality and quantity of production, profits, meeting needs, maintaining survival, and the purpose of earning wages.

\section{AUTHORS' CONTRIBUTIONS}

This research provides an opportunity for the author to contribute to the development of science through studies related to production activities in the economy, thereby contributing ideas that are useful for the field of economics.

\section{ACKNOWLEDGMENTS}

We thank Pendidikan Ganesha University for funding the publication of an article on the Dynamics of Production Activities of Women Farmers in Songan Village, Bangli Regency.

\section{REFERENCES}

[1] I. Ekpe, N. Mat, and R. C. Razak, "The Effect Of Microfinance Factors On Women Entrepreneurs' Performance In Nigeria: A Conceptual Framework.," Int. J. Bus. Soc. Sci., vol. 1, no. 2, 2010.

[2] S. Fadilah, "Kesetaraan gender: Fenomena pergeseran peran ekonomi wanita dari tulang rusuk menjadi tulang punggung," Gend. dan Anak, vol. 1, no. 1, pp. 18-26, 2018.

[3] R. L. Blumberg, "Women's Economic Empowerment As The 'Magic Potion' Of Development?," Pap. Present. 100th Annu. Meet. Am. Sociol. Assoc. Philadelphia., 2005.

[4] L. Sarfaraz, Nezameddin, and A. A. Majd, "The Relationship Between Women Entrepreneurship and Gender Equality.," J. Glob. Entrep. Res., vol. 2, no. 6, 2014.
[5] S. V. A. Jesurajan and M. E. Gnanadhas, "A Study on the Factors Motivating Women to Become Entrepreneurs in Tirunelveli District.," Asian J. Bus. Econ., no. 1, pp. 1-14, 2011.

[6] N. Dangi and Ratika, "Women Entrepreneurship and Growth and Performance of MSMEs in India.," Int. J. Adv. Res. Comput. Sci. Manag. Stud., vol. 2, no. 4, 2014.

[7] E. Ostrom, "Collective action and the evolution of social norms," J. Nat. Resour. Policy Res., vol. 14, no. 3, pp. 137-158, 2000, doi: 10.1080/19390459.2014.935173.

[8] Boediono, Ekonomi Mikro, Cetakan Ke. Yogyakarta: BPFE, 2015.

[9] C. Sa ${ }^{e e}$ diyah, Ekonomi IA. Bandung: PT Remaja Rosda Karya, 2004.

[10] S. Rosyidi, Pengantar Teori Ekonomi: Pendekatan Kepada Teori Ekonomi Mikro dan Makro, Edisi Revi. Jakarta: Rajawali Pers, 2009.

[11] A. Strauss and J. Corbin, DasarDasar Penelitian Kualitatif Tatalangkah dan Teknikteknik teoritisasi Data. Yogyakarta: Pustaka Pelajar, 2015.

[12] J. Saldana, The Coding Manual for Qualitative Researchs. London: Sage, 2009.

[13] J. Saldana, Fundamentals of Qualitative Research. New York: Oxford University Press, 2011. 